\begin{tabular}{|c|c|}
\hline Title & $\begin{array}{l}\text { Effects of diethylstilbestrol and its methyl ethers on aneuploidy induction and microtubule } \\
\text { distribution in Chinese hamster V79 cells }\end{array}$ \\
\hline \multicolumn{2}{|r|}{ ( } \\
\hline Author & $\begin{array}{l}\text { 榊原, 由美子(Sakakibara, Yumiko) } \\
\text { 斎藤, 泉(Saito, Izumi) } \\
\text { 一関, 謙(Ichinoseki, Ken) } \\
\text { 小田, 泰子(Oda, Taiko) } \\
\text { 金子, 元久(Kaneko, Motohisa) } \\
\text { 斎藤, 肇(Saito, Hajime) } \\
\text { 皆玉, 昌彦(Kodama, Masahiko) } \\
\text { 佐藤, 良博(Sato, Yoshihiro) }\end{array}$ \\
\hline Publisher & 共立薬科大学 \\
\hline Publication year & 1991 \\
\hline Jtitle & $\begin{array}{l}\text { 共立薬科大学研究年報 (The annual report of the Kyoritsu College of } \\
\text { Pharmacy). No.36 (1991. ) , p.54- } 54\end{array}$ \\
\hline \multicolumn{2}{|l|}{ JaLC DOI } \\
\hline \multicolumn{2}{|l|}{ Abstract } \\
\hline Notes & 抄録 \\
\hline Genre & Technical Report \\
\hline URL & $\begin{array}{l}\text { https://koara.lib.keio.ac.jp/xoonips/modules/xoonips/detail.php?koara_id=AN00062898-0000003 } \\
\text { 6-0054 }\end{array}$ \\
\hline
\end{tabular}

慶應義塾大学学術情報リポジトリ(KOARA)に掲載されているコンテンツの著作権は、それぞれの著作者、学会または出版社/発行者に帰属し、その権利は著作権法によって 保護されています。引用にあたっては、著作権法を遵守してご利用ください。

The copyrights of content available on the KeiO Associated Repository of Academic resources (KOARA) belong to the respective authors, academic societies, or publishers/issuers, and these rights are protected by the Japanese Copyright Act. When quoting the content, please follow the Japanese copyright act. 
No. $36 \quad 1991$

\title{
Effects of Diethylstilbestrol and Its Methyl Ethers on Aneuploidy Induction and Microtubule Distribution in Chinese Hamster V79 Cells*
}

\author{
Yumiko Sakakibara, Izumi SaIto, Ken Ichinoseki, Taiko Oda, Motohisa Kaneko**, \\ Hazime SAITōo**, Masahiko KodamA ${ }^{* *}$, and Yoshihiro SATō \\ 榊原由美子, 斎藤 泉, 一八関 謙, 小田泰子, 金子元久**， \\ 斎藤 肇**, 児玉昌彦**, 佐藤良博
}

We previously reported that diethylstilbestrol (DES) and its derivatives inhibit the in vitro polymerization of microtubule proteins isolated from porcine brain (Sato et al., J. Biochem. 1987). We found that the presence of the free hydroxy group of DES was indispensable for the inhibition of microtubule assembly.

In the present investigation, this structure-activity relationship was confirmed by the effects of DES and its methyl ethers on chromosome number and the cellular microtubule architecture of Chinese hamster V79 cells, revealed by fluorescent anti-tubulin antibody.

DES induced tetra- and octaploidy and DES monomethyl ether induced only tetraploidy at a much slower rate, whereas DES dimethyl ether was found to be completely inactive. Furthermore, DES was more active than its monomethyl ether in disturbing microtubule formation within cells.

These results support the initial assumption that polyploidy is largely a consequence of the disturbed assembly of microtubules.

* 本報告は Mutation Res., 263, 269-276（1991）に発表.

** 国立がんセンター研究所生物物理部 